ЕПИХИНА Юлия Борисовна - кандидат социологических наук, ведущий научный сотрудник Института социологии Федерального научно-исследовательского социологического центра РАН (117218, Россия, г. Москва, ул. Кржижановского, 24/35, корп. 5; еpikhina@gтаil.com)

\title{
ПОДГОТОВКА ИЗДАНИЙ В ЭПОХУ ЦИФРОВОЙ РЕВОЛЮЦИИ
}

Аннотация. Статья представляет собой рецензию на учебное пособие двух авторов - Е.И. Григорьевой и И.М. Ситдикова - «Электронные издания. Технология подготовки». В пособии, адресованном широкому кругу читателей, раскрываются основные вопросы, связанные с редакторской подготовкой текста электронного издания.

Ключевые слова: электронное издание, редакторская подготовка, цифровые технологии, презентация

Ц ифровая революция, или проникновение цифровых технологий в мир повседневности, изменила отношения человека с текстом. Это изменение имеет не только количественные показатели (например, увеличение доли электронных публикаций и электронных текстов), но и качественные. По мнению Р. Шартье, цифровая революция упразднила жанровое деление, державшееся на различиях в материальном носителе текста, и создала новый жанр - «электронное издание», под которым может подразумеваться любой текст, опубликованный на электронном носителе [Шартье 2006]. Как Французская революция, провозгласившая идеал равенства, цифровая революция уравняла монографию, газетную или журнальную статью, блоггерскую заметку, интернет-сайт, при этом наделив каждый из них одинаковыми обязательствами перед читателем. Эти обязательства продиктованы, прежде всего, особенностями восприятия текста, поданного на электронном носителе.

Как подготовить электронное издание и сделать его максимально читабельным, выигрышным для читательского восприятия? Ответы на эти вопросы можно найти в учебном пособии, написанном Е.И. Григорьевой и И.М. Ситдиковым «Электронные издания. Технология подготовки», вышедшем в издательстве «Юрайт» (2018 г.) [Григорьева, Ситдиков 2018].

Как следует из содержания, пособие станет незаменимым помощником и советчиком в тот момент, когда текст уже готов, написан и возникает задача представить его читателю. Авторы пособия не дают определение того, что следует считать «электронным изданием». Из контекста пособия следует, что электронным изданием можно считать любой текст, имеющий электронный формат: статью, размещенную в Интернете, заметку, книгу и т.д. Отсутствие определения снимает проблему ограничений и границ применимости, задает универсальность теоретических и практических уроков, составляющих пособие, и в целом соответствует универсальности нового жанра, о которой речь шла выше.

Несомненным достоинством пособия является введение в проблематику электронного издания. Авторы последовательно отмечают различия двух форматов - бумажного и электронного, - иллюстрируя собственные тезисы об особенностях электронного издания в сравнении с бумажным. Благодаря этому мы понимаем и можем воочию увидеть, что электронное издание, чем бы на поверку оно ни оказалось (статьей, монографией, букварем или чем-то еще), имеет свою специфику, связанную как с физиологическими особенностями человеческого восприятия, так и технологическим носителем текста.

Рецензируемое пособие состоит из двух частей: первая часть посвящена под- 
готовке электронного издания, вторая часть - подготовке презентаций. При этом презентация рассматривается как особый вид электронного издания. Несомненное достоинство рецензируемого пособия заключается в том, что каждая часть включает как раздел, в котором разбираются теоретические основы подготовки, так и раздел, состоящий из практических уроков. Теоретический курс первой части пособия включает такие важные составляющие электронного издания, как шрифт, структура, таблицы, сноски и ссылки, оглавление и указатели. В практическом разделе первой части разбираются основы форматирования, вопросы настройки стилей, подачи таблиц. Особо следует подчеркнуть внимание авторов к визуальным средствам подготовки электронного текста. Электронный формат и связанные с ним технологические возможности открыли для текста новые визуальные преимущества, которыми также необходимо уметь пользоваться. В первой части пособия особенное внимание уделено как теоретическим основам, так и практическим урокам по обеспечению визуальных компонентов текста: фотографий, изображений, графиков. Вторая часть, посвященная презентации как особому виду электронного издания, раскрывает особенности и «секреты мастерства» создания, подготовки, показа и/ или размещения в онлайн- и офлайн-режимах.

Основная интенция авторов - научить представлять электронное издание в таком виде, чтобы максимальным образом повысить вероятность его прочтения, обеспечить адекватность восприятия при помощи доступных всем инструментов, технических средств. При этом данное пособие не о том, как создать максимальную юзабилити электронного издания, - оно о том, как обеспечить жизнь классическому «бумажному» тексту в новом электронном пространстве.

\title{
Список литературы
}

Григорьева Е.И., Ситдиков И.М. 2018. Электронные издания. Технология подготовки. М.: Юрайт. 439 с.

Шартье Р. 2006. Письменная культура и общество. М.: Новое издательство. 272 с.

EPIKHINA Yulia Borisovna, Cand.Sci. (Soc.), Senior Researcher of the Sociological Institute - branch of the Federal Center of Theoretical and Applied Sociology, Russian Academy of Sciences (bld. 5, 24/35 Krzhizhanovskogo St, Moscow, Russia, 117218; epikhina@gmail.com)

\section{PREPARATION OF PUBLICATIONS IN THE ERA OF DIGITAL REVOLUTION}

\author{
Abstract. The article is a review of the manual of E.I. Grigorieva and I.M. Sitdikov «Electronic publications. Technology of \\ preparation". The manual, addressed to a wide range of readers, reveals the main issues related to the editorial preparation \\ of the text of the electronic publication. \\ Keywords: electronic publication, editorial training, digital technologies, presentation
}

